\title{
Toward Enhancing the Quality and Quantity of Marketing Majors
}

\author{
Priscilla A. LaBarbera and Jeffrey S. Simonoff
}

\begin{abstract}
This article reports the findings of a survey of undergraduate students designed to examine the key factors involved in selecting a marketing major. A discussion follows, dealing with the initiatives undertaken by marketing departments at various universities in an attempt to enhance the quality and quantity of marketing majors.
\end{abstract}

$\mathrm{M}$

arketing departments within many undergraduate business schools are experiencing a decline in the market share of business majors (Hugstad 1997). At the same time, there has been a decline in the quality and quantity of students attracted to a major in marketing (Hugstad 1997; Newell, Titus, and West 1996). Hugstad (1997) observes the irony that marketing departments have been "slow to use the concepts and principles that they teach to manage their own destiny on campus" (p. 12). The marketing profession has not been proactive in attracting gifted students to careers in marketing. In contrast, the accounting profession has invested significant resources in a national marketing research study to determine the reasons why students do and do not choose a major in accounting. That profession also has launched a national promotional campaign to change the image of accounting and provide incentives for more intelligent young people to consider accounting careers (Collins 1987; Gallup Organization 1990; Usry 1987; Williams 1989).

The purpose of this article is to stimulate marketing educator ideas for proactively marketing the major to attract a higher quality and quantity of undergraduate students. Several suggestions are made within the context of the challenges and opportunities inherent in the selection of marketing as a specialization.

Some key factors may work against student selection of marketing (Hugstad 1997; Keillor, Bush, and Bush 1995; Newell, Titus, and West 1996; Swanson and Tokar 1991; Swenson et al. 1993; Tom, O’Grady, and Swanson 1995). For example, many gifted business students select nonmarketing majors early in their academic programs prior to taking the introductory marketing course. A study by Newell, Titus, and West (1996) found that most business students had selected their majors before their sophomore year of college. They found that marketing majors as compared to students selecting other business majors decide on their major later during their academic careers. Keillor, Bush, and Bush (1995) found that in contrast to marketing majors, nonmarketing business majors are influenced by lower division classes when selecting a major.

Regarding this issue, Hugstad (1997) posits that marketing is often a "default major for those business majors who cannot successfully complete accounting or finance programs" (p. 6). In contrast to selected quantitative courses such as introductory accounting, economics, and statistics, the American Assembly of Collegiate Schools of Business (AACSB) accreditation standards call for the majority of business courses to be taken during the last 2 years (AACSB 1995). Therefore, Hugstad (1997) reasons that having experienced success in quantitative courses, many strong students choose to continue down the path of accounting or the closely aligned path of finance

which have an image of a rigorous and professional career path. ... Because it is not designed to be sampled early in the core, marketing too often must rely on those students who either are not very successful in their early business school courses or students who continue to be uncertain about their major and career ambitions. (p. 6)

That quantitative orientation is an important factor in the choice of marketing as a business major has some empirical support. As compared with nonmarketing majors, Newell, Titus, and West (1996) found that marketing majors rate themselves as significantly lower in possessing quantitative skills and attribute significantly less importance to careers that involve working with numbers.

Priscilla A. LaBarbera is an associate professor of marketing and director of the Undergraduate Marketing Program in the Department of Marketing, Leonard N. Stern School of Business, at New York University. Jeffrey S. Simonoff is a professor of statistics in the Department of Statistics and Operations Research, Leonard N. Stern School of Business, at New York University.

Journal of Marketing Education, Vol. 21 No. 1, April 1999 4-13 (C) 1999 Sage Publications, Inc. 
Career opportunities and salaries also are significant factors in the selection of a business major (Cebula and Lopes 1982; Keillor, Bush, and Bush 1995; Newell, Titus, and West 1996; Swanson and Tokar 1991; Swenson et al. 1993). Newell, Titus, and West (1996) found that across the business students surveyed, career factors had greater importance on choice of a major as compared to other factors including course work, curriculum, and faculty reputation. Salaries corresponding to various career choices significantly influence students' choice of a major (Cebula and Lopes 1982; Swanson and Tokar 1991; Swenson et al. 1993). However, in comparison with entry-level positions in other business areas, entry-level jobs in marketing and advertising offer salaries that are considerably lower (Friedly 1997; Steinfeld 1997).

A further obstacle to attracting majors is that marketing departments may not perceive the need to improve the standing of their discipline as an undergraduate major (Hugstad 1997). Empirical data suggest that there is a discrepancy between the perceived status ranking of the marketing major within and outside of the marketing department (Tom, O'Grady, and Swanson 1995). Tom, O'Grady, and Swanson (1995) found that within the marketing department, both student majors and faculty perceive the status ranking of the marketing major to be inflated compared with the relative status ranking of marketing majors by students from other departments. Affecting the perceived status of undergraduate majors are internal and external factors. The Tom, O'Grady, and Swanson (1995) study found that in addition to the quality of the program, the key criteria used by respondents to formulate the prestige rankings of the majors were public perception and demand for graduates. Swenson et al. (1993) found that some careers in marketing, such as personal selling, have a negative image.

However, there are advantages to a major in marketing and opportunities to attract undecided students. For example, students perceive that marketing offers a wide variety of career opportunities in comparison with other majors (Keillor, Bush, and Bush 1995; Newell, Titus, and West 1996). In addition, research has shown that it is important to reach the undecided students with information regarding majors early in their academic careers, and both parents and peers are important influencers in the selection of a major (Keillor, Bush, and Bush 1995; Newell, Titus, and West 1996).

The present study seeks to stimulate educator ideas by reporting on proactive efforts of various marketing departments to enhance the quality and quantity of students majoring in marketing. To provide a context for these recommendations, an empirical study was conducted with a twofold purpose. First, the study investigates the challenges of attracting students to a major in marketing. Second, the study seeks to understand the opportunities to positively influence students to choose marketing as a major. Both the challenges and opportunities need to be considered in programmatic efforts to market the major.

\section{METHODOLOGY}

In-depth interviews were conducted with New York University's Stern School of Business undergraduate marketing majors and nonmajors, Stern academic advisers, and career placement staff regarding the choice of a business school major in general and marketing as a chosen major in particular. These interviews, along with the literature review, provided guidance in developing the specific content of the survey questions.

New York University is a private urban university with a total of about 50,000 students. There are 16,253 undergraduate students with 2,100 attending the business school. During the Spring 1996 and Fall 1996 semesters, students were surveyed in one of two required courses (Introduction to Marketing or Introduction to Finance) as well as Consumer Behavior, which is a requirement for marketing majors. The data collection was designed so that there was no duplication of student respondents. (To guard against the possibility of respondent duplication, sections of the various courses that met at the same time were surveyed.)

Two MBA-level research assistants administered the self-completion survey, which took about 10 to 15 minutes to complete. There was a $100 \%$ response from the students in these classes. A total of 364 undergraduates (representing more than $17 \%$ of the total population of undergraduates attending the business school) completed the survey. Of the total sample, about $76 \%$ were juniors and $24 \%$ were seniors, representing 52\% male students and $48 \%$ female students.

The survey instrument was designed to investigate the challenges and opportunities regarding the attraction of quality students to a major in marketing. One series of 5-point Likert-type items dealt with the importance of various factors in choosing a major in general, while the second series of Likert-type items focused on the level of agreement with statements dealing specifically with the marketing major. Respondents also were asked about the timing of the major decision and were given the opportunity to add comments by means of a few open-ended questions. A copy of the survey (in MS Word and html formats) and the resultant data (in ASCII format) can be obtained via the World Wide Web at the location http://www.stern.nyu.edu/ plabarbe/survey/.

Among the items relating to the choice of a major in general were statements about the importance of the quantitative or qualitative nature of the courses and difficulty of the course work. Other items dealt with the career aspects of the major and the importance of parental and peer influence in selecting a major.

With respect to the series of items directly relating to a marketing major, the statements dealt with respondents' level of agreement regarding the quantitative aspect of marketing course work and difficulty of the marketing major. Other items focused on marketing careers, image, and prestige.

The relationships between responses to the questions and major status (marketing / nonmarketing / undecided) were 
tested statistically by using nominal logistic regression models. The response variable representing a student's major has three categories: marketing, nonmarketing, and undecided. Let $p_{m i}, p_{n i}$, and $p_{u i}$ be the probability that student $i$ is a marketing, nonmarketing, or undecided major, respectively, and $x_{i}$ the value of a predicting variable $x$ for that student. The nominal logistic regression model represents these probabilities using logistic functions:

$$
\begin{aligned}
& \log _{e}\left[\frac{p_{n i}}{p_{m i}}\right]=\beta_{0 n}+\beta_{1 n} x_{i}, \\
& \log _{e}\left[\frac{p_{u i}}{p_{m i}}\right]=\beta_{0 u}+\beta_{1 u} x_{i} .
\end{aligned}
$$

In this example, the logarithm of the odds of being a nonmarketing major relative to being a marketing major and the logarithm of the odds of being an undecided major relative to being a marketing major are modeled as being (different) linear functions of the predictor $x$. That is, the category of marketing major is the reference category. Given that any of the three categories can be chosen as the reference category without changing the model, the category that is most relevant for the specific hypothesis being examined can be used. In addition to examining an overall measure of the statistical significance of the predictor $x$ as a classifier of the three categories, the statistical significance of the individual slope coefficient $\beta_{1 n}$ or $\beta_{1 u}$ can be used to assess whether the predictor differentiates between the individual category and the reference category. The model also can be generalized easily to include multiple predictors.

The formal model testing and fitting will not be described in detail here; a summary of the results of these model fits may be obtained at the World Wide Web location mentioned earlier. Unless otherwise stated, all of the effects discussed here were statistically significant at no more than a .005 level based on the nominal logistic regression fit.

\section{FINDINGS AND DISCUSSION}

Our data are consistent with the literature regarding some of the challenges that the marketing discipline faces in attracting a higher quality and quantity of undergraduate students to a major (Hugstad 1997; Keillor, Bush, and Bush 1995; Newell, Titus, and West 1996; Swanson and Tokar 1991; Swensen et al. 1993; Tom, O'Grady and Swanson 1995). These include the early attraction of some students to more quantitative majors, the association of more impressive career opportunities and starting salaries with other nonmarketing business majors, and a less favorable image toward marketing as a discipline and as a career. However, there are opportunities to influence students along with their parents and peers during the process of deciding on a major (Bebko 1994; Newell, Titus, and West 1996; Randahl 1991).
The data demonstrate that when compared with marketing majors, nonmarketing majors select a major earlier in their academic careers. About $30 \%$ of the respondents decided on their majors during their junior or senior years, and of these respondents, $42 \%$ chose marketing. This can be compared with only $32 \%$ of the students who made earlier decisions about being marketing majors. Figure 1 illustrates this pattern graphically. The figure shows the cumulative percentages of respondents according to when they chose their major, separated by whether the respondent is a marketing major or a nonmarketing major. At every time level through sophomore year, the proportion of students who had chosen their major by that time was at least 10 percentage points higher for nonmarketing majors compared with marketing majors, illustrating that nonmarketing majors were noticeably more likely to choose at the earlier times.

A significant influence on the decision of nonmarketing majors seems to be the quantitative courses that the AACSB permits to be taken prior to the junior year in college when other core business courses, including marketing, are first taken (Hugstad 1997). The findings illustrate that in comparison with nonmarketing majors, marketing majors are more qualitatively than quantitatively oriented. Roughly $10 \%$ of marketing majors view the quantitative nature of course work as not at all important, compared with $5 \%$ of nonmarketing majors; $12 \%$ of marketing majors view it as extremely important, compared with $16 \%$ of nonmarketing majors. The results are similar (but in the opposite direction) for the variable representing importance of the qualitative nature of course work, with $77 \%$ of marketing majors finding this important or extremely important, compared with $63 \%$ of nonmarketing majors.

Figure 2 gives a graphic representation for the variable referring to the quantitative nature of the course work. The responses of the students who had not yet decided their majors are much more similar to those of the nonmarketing majors than those of the marketing majors. While $27 \%$ of marketing majors view the quantitative nature of a major as unimportant, only $21 \%$ of those who are undecided do, similar to the $20 \%$ of nonmarketing majors. That is, students who did not rate quantitative course work as important were more likely to have chosen a marketing major. These findings are consistent with Hugstad's (1997) hypothesis that marketing is often a "default" major for business students who either are not highly successful in their early accounting and economics courses or who are uncertain about their majors and careers.

With respect to career considerations, more nonmarketing majors as compared with marketing majors disagree that marketing offers attractive career opportunities and competitive starting salaries, although these differences are not statistically significant based on the logistic regression fitting. Figure 3 summarizes the pattern with respect to the level of agreement with a statement that the marketing field holds many career opportunities for new graduates. The weaker 


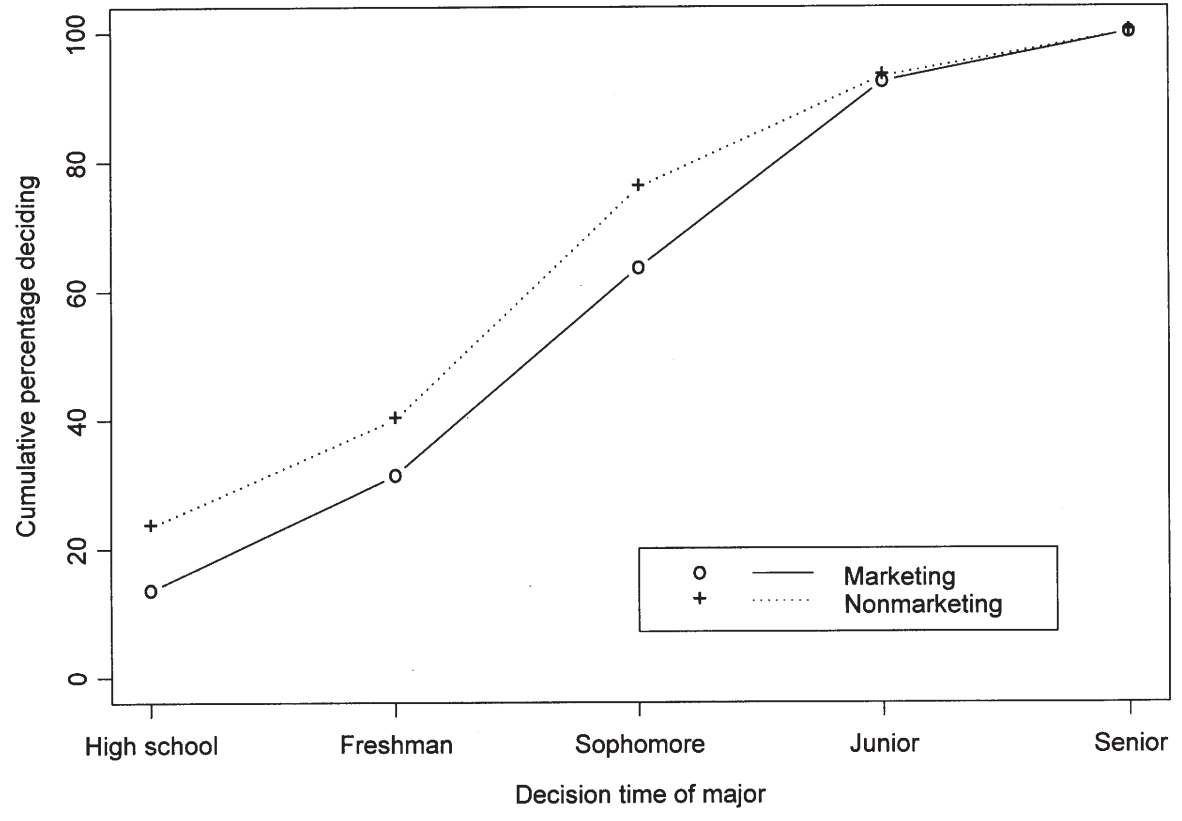

FIGURE 1: Cumulative Percentages of Time by When Students Decided Their Major, Separated by Status as a Marketing Major or Nonmarketing Major

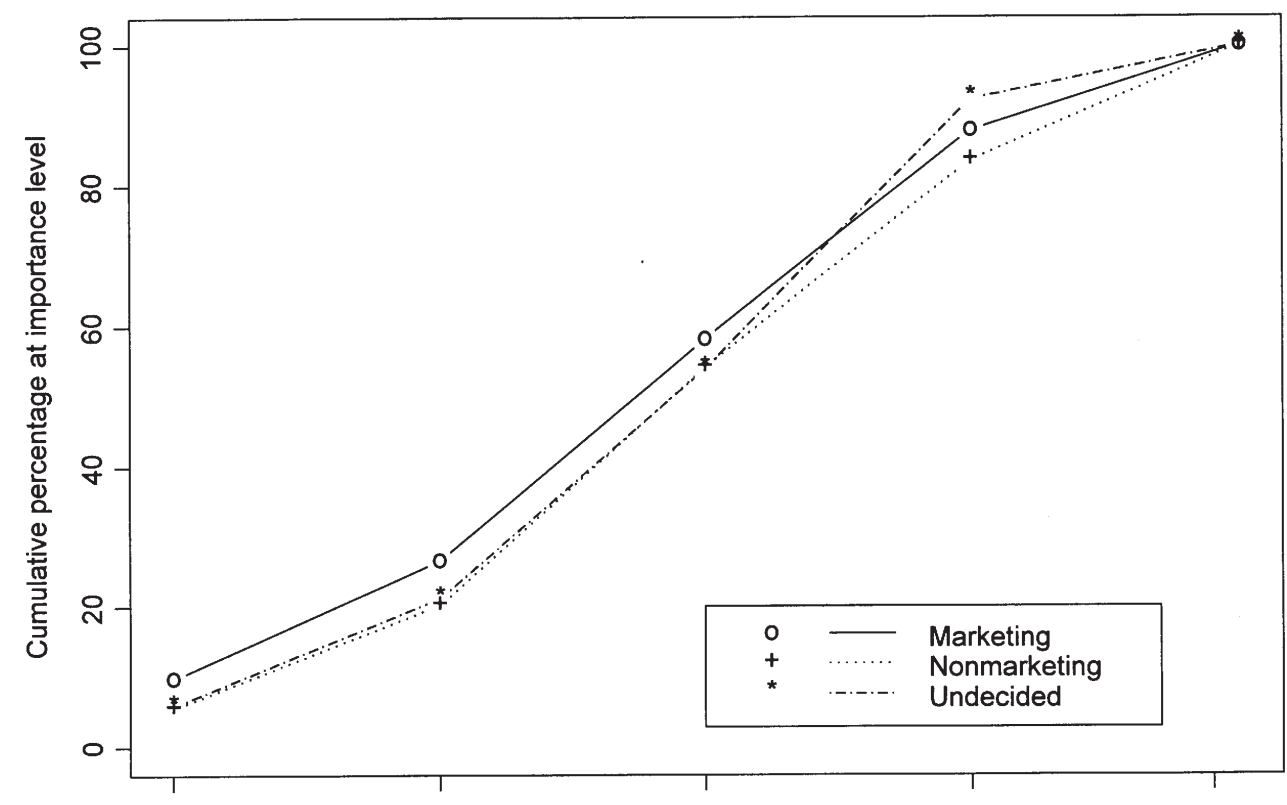

Not at all important

Extremely important

Importance of quantitative nature of major

FIGURE 2: Cumulative Percentages of Importance of Quantitative Nature of Major in Choosing Major, Separated by Status as a Marketing Major, Nonmarketing Major, or Undecided 


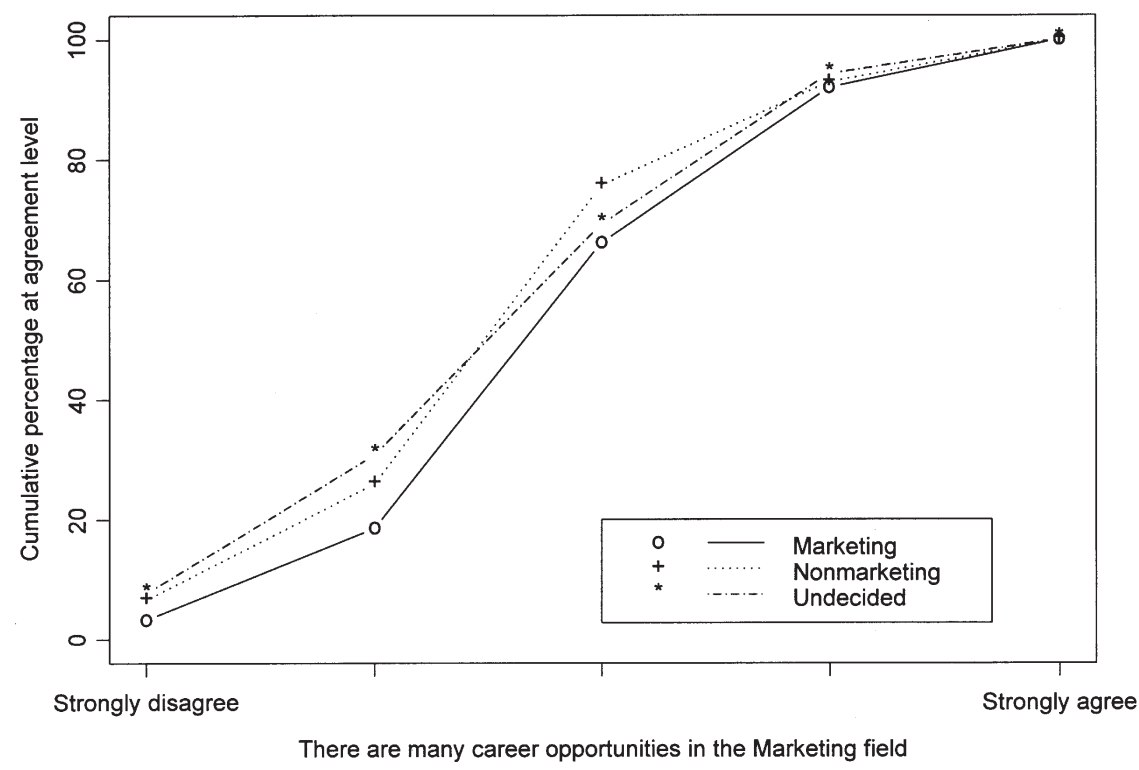

FIGURE 3: Cumulative Percentages of Agreement that the Marketing Field Offers Many Career Opportunities, Separated by Status as a Marketing Major, Nonmarketing Major, or Undecided

nature of the distinction between the three major status levels is apparent from the plot, but the consistent position of the cumulative percentage line for marketing majors below that for nonmarketing majors shows that marketing majors are more optimistic about the marketing job market than nonmarketing majors. Indeed, while $34 \%$ of marketing majors agreed or strongly agreed with the statement "There are many career opportunities in the marketing field for new graduates," only $24 \%$ of the nonmarketing majors agreed or strongly agreed with this statement.

Those who are undecided occupy a position between the other two, which is perhaps not surprising. What is interesting, however, is that those who are undecided are characterized by extreme feelings in both directions. Thirty-one percent of those who are undecided disagreed or strongly disagreed with the positive statement about marketing career opportunities, which is more than either of the other two groups. However, $31 \%$ also agreed or strongly agreed with the statement, which is almost as many as in the marketing major group. (The percentage picking the middle Likert-type value is much lower for those who are undecided.) This latter group of undecided students would presumably constitute an important target market for marketing department recruitment.

Opinions about salary size competitiveness follow a similar pattern, with $22 \%$ of marketing majors and $12 \%$ of nonmarketing majors agreeing with the statement "The field of marketing offers competitive starting salaries relative to other business fields." The most important point about these findings is that all groups have a pessimistic view of the marketing job market and the competitiveness of starting salaries in the field.

Differences of opinion regarding the status and image associated with marketing were much stronger in the study. Compared with marketing majors, nonmarketing majors believe that marketing course work is less demanding and challenging and marketing careers are less respected when compared with other careers such as accounting or finance. While $18 \%$ of marketing majors strongly agree with the statement "Marketing course work is demanding and challenging," only $8 \%$ of the nonmarketing majors do. Furthermore, whereas only $37 \%$ of the nonmarketing majors strongly agree or agree with the statement, $65 \%$ of the marketing majors indicated agreement. Once again, those who are undecided are characterized by extreme feelings in both directions. While $17 \%$ of undecided students disagree or strongly disagree with the statement (almost as many as the $19 \%$ of nonmarketing majors), 58\% agree or strongly agree with it. See Figure 4 for a graphic representation of this pattern.

Another survey statement indicating the perception of the challenge afforded by the marketing major, "A marketing major is less difficult than other business school majors," was also examined. The results here were similar, but less clearcut. Although there was a statistically significant difference between marketing majors and nonmarketing majors, it was weaker $(p=.018$ vs. $p<.001)$.

Two survey items address the question of comparative status and image of the marketing profession: "A career in 


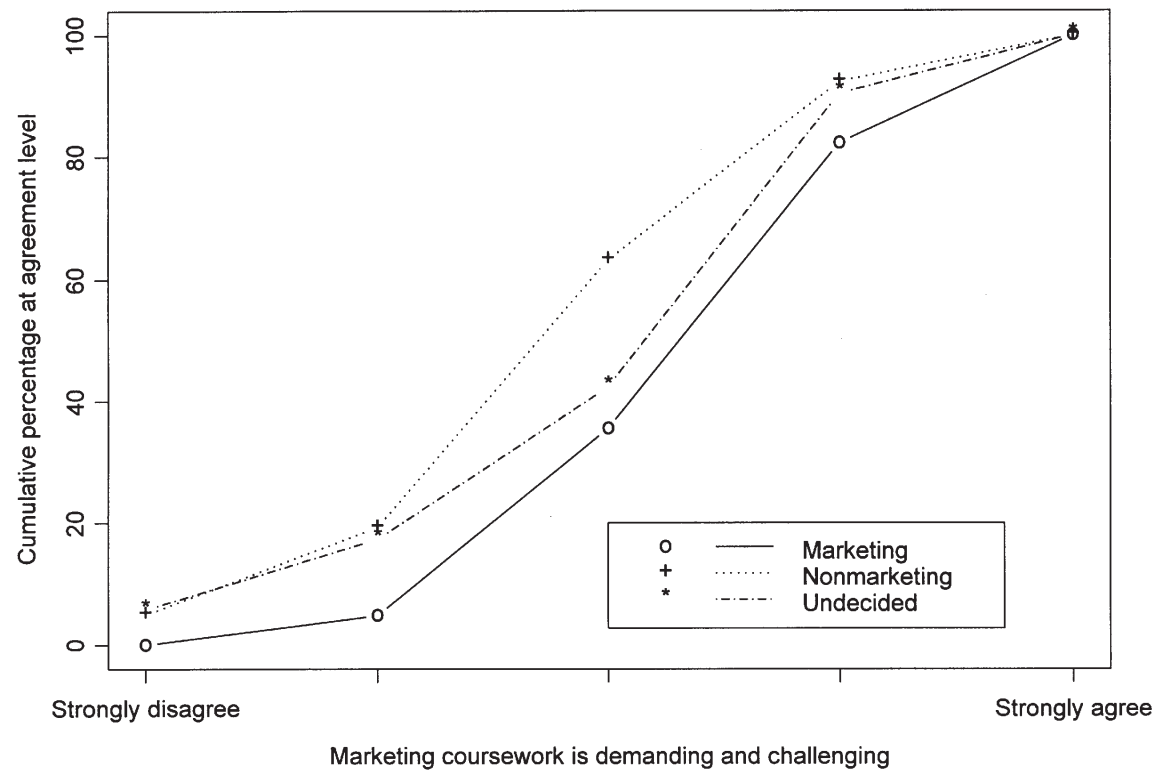

FIGURE 4: Cumulative Percentages of Agreement that Marketing Course Work Is Demanding and Challenging, Separated by Status as a Marketing Major, Nonmarketing Major, or Undecided

marketing is as well-respected as a career in accounting/finance" and "The field of marketing offers a better "quality of life' than other business school majors." Nonmarketing majors are more likely to disagree that the marketing major is as well respected as accounting and finance, and that marketing offers a better "quality of life," while marketing majors are more likely to agree with these statements. For example, $46 \%$ of marketing majors agree with the first statement and $44 \%$ agree with the latter one; this can be contrasted with $21 \%$ and $19 \%$, respectively, of nonmarketing majors. Figure 5 gives a graphic representation of the responses to the first statement and makes clear that respondents who were undecided about their majors were fairly evenly split in their opinions between the positions of the marketing and nonmarketing majors.

\section{IMPLICATIONS AND IDEAS}

These findings provide some guidance for marketing educators interested in recruiting a higher quality and quantity of majors. We now discuss several initiatives undertaken by the marketing department at New York University's (NYU) Stern School of Business and marketing departments at other universities with a view toward stimulating ideas to proactively market the major.

The primary opportunity segments include those students who opt for nonmarketing majors and those who are undecided about their majors. It is important to educate the prospective students about the benefits of a marketing major as well as their parents and peers, who are important sources of input when deciding on a major.

Activities can be undertaken to showcase marketing as a discipline and career possibility early in the college experience. The marketing faculty at NYU has developed informational materials for distribution during various outreach opportunities with high school students, students about to enter NYU, and students who are currently attending NYU. These events include career fairs and seminars, open houses, and student club meetings, which are sometimes attended by parents as well as prospective and current students. These events present key opportunities for gaining access to students and their parents prior to the freshman year or during the first 2 years at NYU.

Such access, including to parents, is important, as students who are undecided about their majors are relatively sensitive to peer and parental influence in choosing a major. While $72 \%$ of marketing majors and $65 \%$ of nonmarketing majors do not consider peer pressure important, only $44 \%$ of those who are undecided feel this way (see Figure 6). The corresponding figures for parental pressure are $69 \%$ of marketing majors, $54 \%$ of nonmarketing majors, and only $44 \%$ of undecided students. Thus, while students who are already marketing majors report being relatively unaffected by peer and parental pressure, students who have not yet decided on a major could be influenced by positive impressions of peers and parents regarding the marketing major.

The informational materials that have been developed include a handout on careers and a student handbook on 


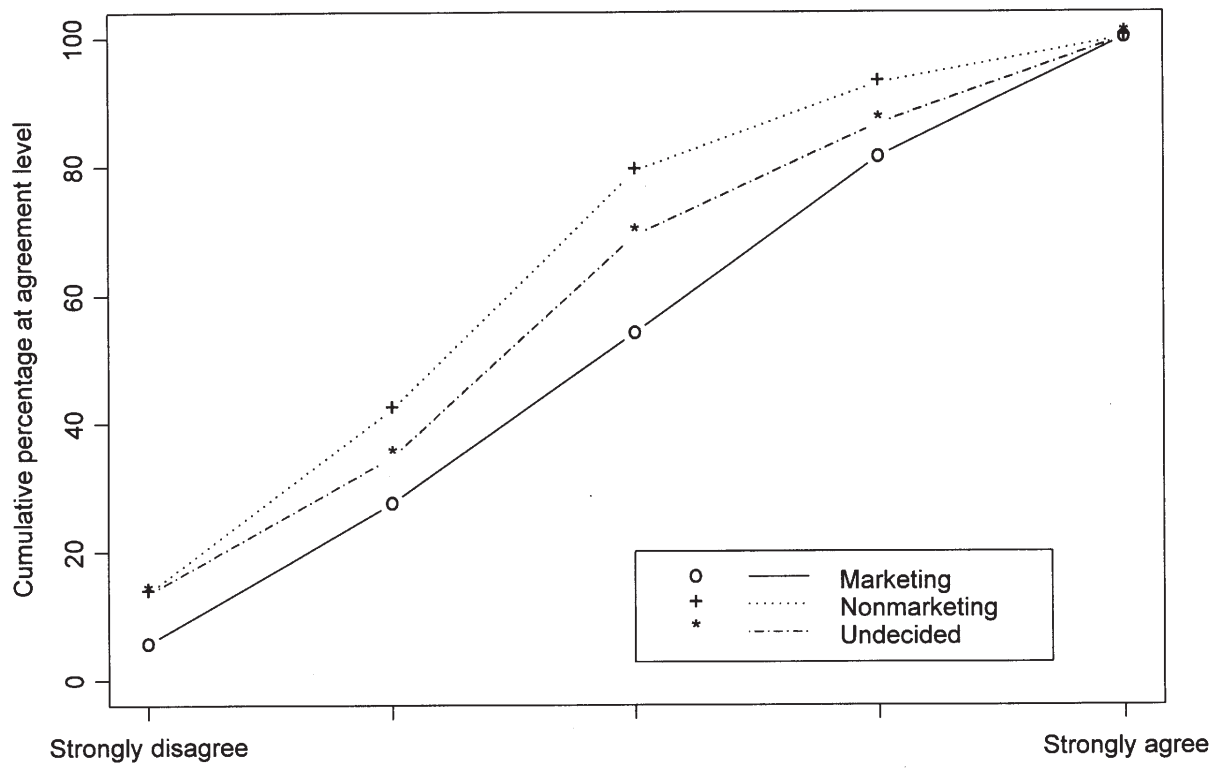

A marketing career is as well-respected as accounting/finance

FIGURE 5: Cumulative Percentages of Agreement that a Marketing Career Is as Well Respected as One in Accounting or Finance, Separated by Status as a Marketing Major, Nonmarketing Major, or Undecided

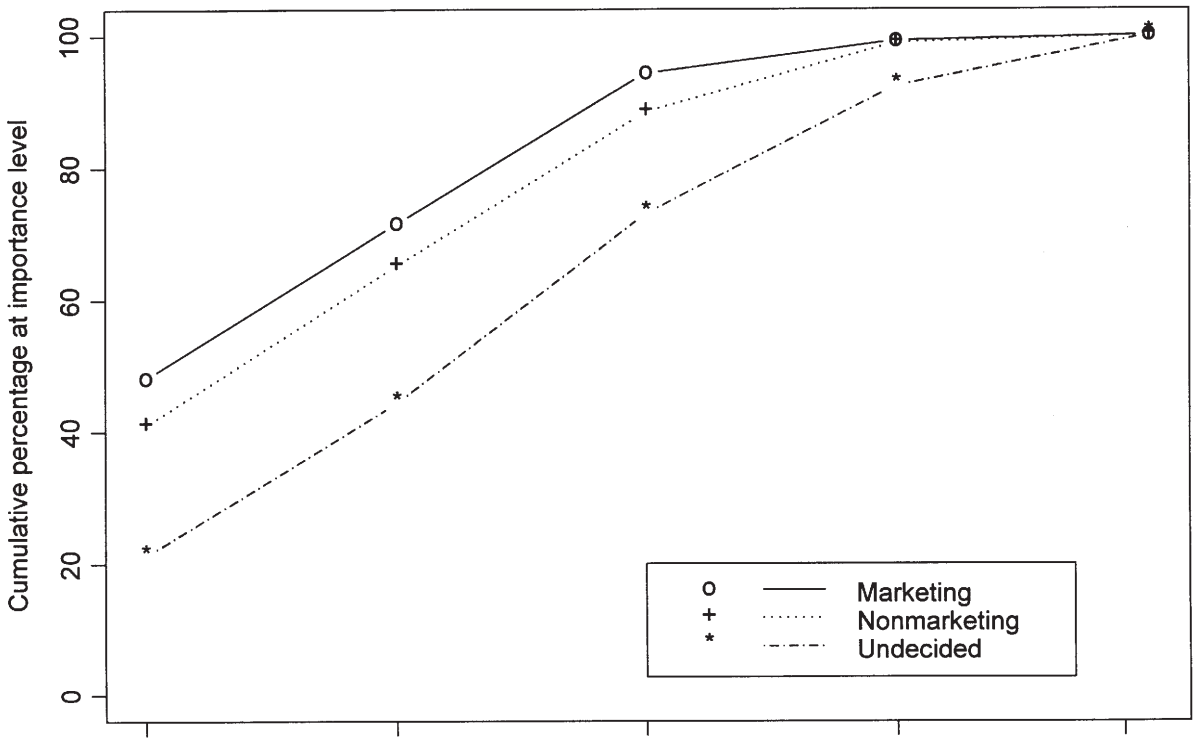

Not at all important

Extremely important

Importance of peer pressure

FIGURE 6: Cumulative Percentages of Importance of Peer Pressure in Choosing a Major, Separated by Status as a Marketing Major, Nonmarketing Major, or Undecided 
marketing as a major and a comajor. The handout on careers, which is regularly updated, contains career placement office statistics on the recently graduated marketing majors, specifying starting positions broken down by percentage placement (e.g., $40 \%$ in sales, 35\% in retailing, etc.), average starting salaries received by students accepting positions in the various marketing careers, and examples of recruiting organizations.

The handbook outlines the benefits of majoring or comajoring in marketing. It contains information on the marketing double major options within the business school such as marketing/finance, marketing/information systems, and marketing/international business. There is additional information on majoring in marketing while minoring in eight selected disciplines within NYU's College of Arts and Sciences, such as politics or journalism. For each option, the handbook lists a sample of the skills that a marketing major alone or in conjunction with a second major or a minor would offer, suggested courses to take, possible careers, entry-level career titles, and sample recruiting organizations.

In terms of attracting a higher quality student to marketing as a major, the marketing department has started to send congratulatory letters to students receiving an A or A-in the core introductory marketing course. These letters encourage students to continue with, or consider, a major/comajor in marketing and invite students to visit the undergraduate director to discuss a major in marketing. In addition, some of the marketing major informational materials are enclosed with the letters. Scholarship money recently was given to the marketing department at NYU. In an attempt to attract strong students to a major or comajor in marketing, two annual scholarships of $\$ 1,000$ each have been made available to outstanding juniors who choose marketing as a major area of study.

Compared with marketing majors, nonmajors do not believe that marketing course work is demanding and challenging. This finding may be the result of the actual or perceived course content as well as the skills, motivation, intelligence, and so forth of the students attending advanced marketing classes. In terms of the actual course content, the marketing department has worked to develop a rigorous and pedagogically rich introduction to the marketing core class. Efforts have been made to standardize this course across sections to maintain quality control. There are plans to review the contents of other courses in the marketing curriculum to encourage relevant and high-quality content.

At NYU's business school, finance majors currently comprise $32 \%$ of the undergraduate majors. In terms of market share, finance majors are followed by accounting (15\%), marketing (14\%), international business (14\%), information systems (10\% and growing rapidly), management (7\%), and various others $(8 \%)$. Given the large numbers of finance majors and the complementary nature of marketing and finance as areas of joint study, the marketing department, in cooperation with the finance department, has developed a multipanel folder that outlines the advantages and opportunities of a double major in finance and marketing. Highlighting this double major option is an attempt to reposition marketing as a complement with other areas that attract students with strong quantitative skills.

The folder contains relevant facts regarding the value of a finance/marketing double major that combines the benefits of both technical/analytical skills and behavioral/creative knowledge. The brochure points out that one third of the business school's undergraduate finance majors accept positions in financial sales/brokerage services. It is underscored that a degree that combines training in marketing along with finance can enhance a student's marketability and skill proficiency. The brochure reviews the skills that a double major in finance/marketing will offer to students, course requirements for double majors, and information regarding employment opportunities. The marketing department has recently introduced a new course for undergraduates, Marketing Financial Services, to directly bridge the two disciplines for interested students.

Aside from business school students, marketing classes are of interest to students from other NYU colleges such as the film school and the College of Liberal Arts. In an attempt to also appeal to these students, the marketing department has recently introduced full-length and half-semester ("mini") courses that correspond to student marketing career-related interests. These courses include Entertainment Marketing, Media Planning, Broadcast Marketing, and Marketing on the Internet. Information about these new courses has been disseminated to advisers in other NYU colleges as well as business school advisers and business students. Enrollment figures indicate that the interest level in these courses is high and they are attracting students from undergraduate schools across campus.

The present study also found that while marketing majors are somewhat more hopeful, respondents generally feel rather pessimistic about starting salaries and career options with an undergraduate major in marketing. These perceptions are in line with the facts. Compared with a mean 1996 salary of about $\$ 30,000$ for NYU undergraduate students starting with positions in marketing, the mean salaries for finance, accounting, and information systems are $\$ 37,000, \$ 34,000$, and $\$ 41,500$, respectively. In fact, with the exception of entry-level jobs in communications, undergraduate students who are placed in marketing positions have the lowest mean starting salary in comparison with not only other options within the business school but across all major choices at NYU (Steinfeld 1997). Combining a marketing major with a quantitative discipline may assist students in obtaining higher paying positions.

At NYU, $40 \%$ of graduating marketing majors currently accept sales positions and 35\% accept offers in retailing. These career options are not of interest to many business students (Castleman et al. 1995). The marketing department is 
involved in activities that are aimed at expanding the career opportunities for marketing students. For example, efforts are being made to encourage the university placement office to attract recruiters who offer wider career options for marketing majors. Marketing faculty members are beginning to meet with recruiters to develop networking relationships.

At the present time, the business school at NYU does not permit college credit for internships. This policy works against students who want to obtain entry into organizations that do not typically recruit business undergraduates for paying positions, such as leading advertising agencies or entertainment companies. Many of these "glamour" companies have a policy of offering internship for college credit versus salary. To provide access for students, the marketing department has developed a proposal for the undergraduate program review committee to consider an internship for academic credit option. At the same time, efforts are being made to work with various marketing and advertising professional associations to develop noncredit-paying internship programs with leading organizations. The goal is to develop internships that will permit NYU business school students to have access to blue-chip companies while obtaining global work experience.

There seems to be movement toward more proactive marketing of the marketing major at other universities as well. For example, the marketing department at the University of Texas (UT) at Austin has hired staff to develop a multimedia presentation for all business freshmen (Rogers 1997). Data are presented in an entertaining way, demonstrating that marketers can make substantial salaries and have a variety of career options such as consulting, banking, and retailing. The presentation also introduces students to the changing nature of sales positions, such as at Procter \& Gamble, where the sales role is being reshaped into a highly analytical, consulting-type function. An additional initiative at UT Austin is the development of a career/academic counseling resource available to marketing majors only. Services include mock interviews, resume preparation, job search strategies, and advice on course selection.

Youngman (1996) reports on recruitment and retention strategies involving marketing majors at Salt Lake Community College (SLCC). In the winter of 1994, that marketing department implemented an educational marketing plan that focused on customer service and the "personal touch." Primary target markets included SLCC marketing majors and concurrently enrolled high school marketing students, while secondary targets included SLCC business and general studies majors, high school students participating in marketing events, education administrators, and businesses. Among the initiatives were telephone calls to, and personal interviews with, marketing majors; birthday letters; and letters sent to general studies and business majors suggesting that they enroll in a marketing class. Letters also were sent to employers to inform them that their employees had successfully completed marketing courses that were relevant to their positions. Following implementation of the plan, the marketing department experienced enrollment increases during the Spring 1994 and Fall 1995 semesters. It seems that efforts to market the marketing major at various universities are having payoffs.

\section{CONCLUSION}

Given the limitation of a single university sample, the findings and implications may not be widely applicable to other marketing departments. While the present findings are largely consistent with other empirical work (e.g., Keillor, Bush, and Bush 1995; Newell, Titus, and West 1996; Tom, O'Grady, and Swanson 1995), an important next step is an extensive research study such as that undertaken by the accounting profession. Resources were invested in a national marketing research study to investigate reasons why students decide for or against an accounting major. A national promotional campaign to change the image of accounting and encourage intelligent students to consider accounting careers was also undertaken (Collins 1987; Gallup Organization 1990; Usry 1987; Williams 1989). In addition to such a national professional effort, marketing faculties should survey their students to identify and respond to the recruitment challenges that individual departments face.

What might also be required is internal marketing within departments as well as external marketing to recruit potential majors. Hugstad (1997) argues that the "inflated self-image of marketing faculty and students may mask the need for marketing departments to deal with important issues regarding the size and composition of the existing pool of marketing majors" (pp. 6-7). It is necessary to impress on marketing faculty that a problem exists and that they must devote energies to the recruitment of students. An initial approach may include the circulation of academic papers such as those published by Hugstad (1997) and Tom, O'Grady, and Swanson (1995), followed up by departmental meetings to discuss the situation. Faculty members need to reach an agreement on a recruitment strategy that fits within the departmental mission and resources. While there are significant hurdles on both the internal and external fronts, marketing faculty have the advantage of being well equipped with the expertise necessary to meet the challenge.

\section{REFERENCES}

American Assembly of Collegiate Schools of Business (AACSB). 1995. AACSB standards for business accreditation. Guide for self-evaluation. St. Louis, MO: American Assembly of Collegiate Schools of Business.

Bebko, Charlene Pleger. 1994. Awareness, timing and reasons for choosing marketing as a college major. In Proceedings of the Academy of Marketing Science annual conference. 1994: Development in marketing science, vol. 17, edited by E. J. Wilson and W. C. Black, 123-27. Marquette, MI: Academy of Marketing Science. 
Castleman, Amanda, Elise Wolfgram, Charlie Ornstein, and Melissa E. James. 1995. Postcards from the class of '95. Sales and Marketing Management 147:73-77.

Cebula, Richard J., and Jerry Lopes. 1982. Determinants of student choice of undergraduate major field. American Educational Research Journal 19 (summer): 303-12.

Collins, Steven. 1987. Recruiting and retaining the best and brightest in today's economic market. Journal of Accountancy 63 (February): 52-58.

Friedly, Megan. 1997. Internships good for opening doors. Advertising Age, 1 December, S14.

Gallup Organization. 1990. Accounting Recruiting Study: Focus Group Report. Princeton, NJ: Gallup Organization.

Hugstad, Paul. 1997. Marketing the marketing major. Journal of Marketing Education 19:4-13.

Keillor, Bruce D., Robert P. Bush, and Alan J. Bush. 1995. Marketing-based strategies for recruiting business students in the next century. Marketing Education Review 5 (3): 69-80.

Newell, Stephen J., Philip A. Titus, and James S. West. 1996. Investigating the undergraduate student decision-making process of selecting a business specialization: A comparison of marketing and nonmarketing business students. Journal of Marketing Education 18 (fall): 57-67.

Randahl, Gloria J. 1991. A topological analysis of the relations between measured vocational interests and abilities. Journal of Vocational Behavior 38 (3): 333-50.
Rogers, Tony. 1997. E-mail communication with authors, 27 March.

Steinfeld, Trudy. 1997. New York University Office of Career Services. An analysis of New York University's class of 1996. January. Unpublished university report.

Swanson, Jane L., and David M. Tokar. 1991. College students' perceptions of barriers to career development. Journal of Vocational Behavior 38 (1): 92-106.

Swenson, Michael J., William R. Swinyard, Frederick W. Langrehr, and Scott M. Smith. 1993. The appeal of personal selling as a career: A decade later. Journal of Personal Selling and Sales Management 13 (winter): 51-64.

Tom, Gail, Devin O'Grady, and Stoakley Swanson. 1995. The ethnocentric perspective of marketing students and faculty towards business majors. Marketing Education Review 5 (summer): 19-24.

Usry, Milton F. 1987. Accounting student quality. CPA Journal 57 (September): $16-17$.

Williams, Doyle Z. 1989. Accounting education: A statistical survey 1987-88. New York: American Institute of Certified Public Accountants.

Youngman, Curtis. 1996. Recruitment combined with retention strategies results in institutional effectiveness and student satisfaction. Fifth Annual International Conference for Community \& Technical College Chairs, Phoenix/Mesa, Arizona, February: 396-99. 